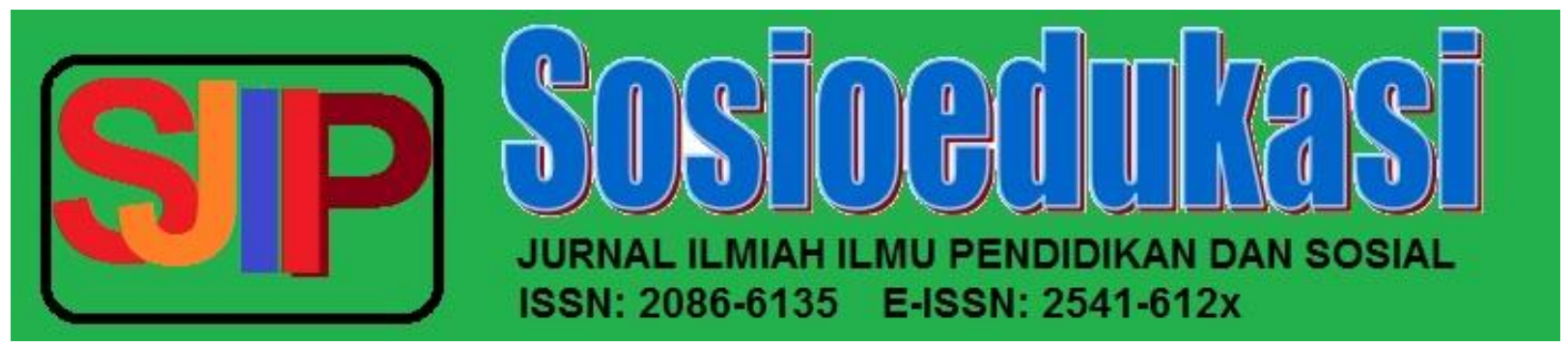

November Vol.9 No. 2 Tahun 2020 https://ejournal.unibabwi.ac.id/index.php/sosioedukasi/index

\title{
JURIDICAL REVIEW OF THE AUTHORITY OF THE CONSTITUTIONAL COURT IN RESOLUTION OF GENERAL ELECTION DISPUTES FOR REGIONAL HEAD
}

\author{
Micael Josviranto \\ Law Study Program, Faculty of Law, Nusa Nipa University \\ micaeljosviranto23@gmail.com
}

\section{ARTICLE HISTORY}

Received : 2310-2020

Revised : 18-10-20120

Accepted : 17-11-2020

KEYWORDS

Authority;

Constitutional Court;

Regional Head General

Election Dispute Resolution;

\section{ABSTRACT}

purpose of this research is to find out what is the legal basis for the authority of the Constitutional Court in resolving disputes over the results of the General Election of Regional Heads in Indonesia and how the effectiveness of the authority of the Constitutional Court in disputes over Regional Head General Election. The method used in this research is juridical normative, namely, the materials collected by conducting a literature study. The authority of the Constitutional Court in judging at the first and last levels whose decisions are final in deciding disputes regarding general elections, there are several paragraphs that discuss the extent to which the authority of the Constitutional Court in resolving disputes over the General Election of Regional Heads has been contained in Article 157 of Law Number 102016 concerning the Second Amendment to Law Number 1 of 2015 concerning Stipulation of Government Regulations in Lieu of Law Number 1 of 2014 concerning the Election of Governors, Regents and Mayors which form the legal basis for the authority of the Constitutional Court in resolving disputes over the results of the General Election in Indonesia.

This is an open access article under the CC-BY-SA license.

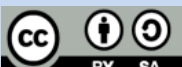

\section{INTRODUCTIONS}

Democracy is the embodiment of Indonesian society based on the 1945 Constitution of the Republic of Indonesia, reflecting the people's sovereignty in the hands of the people implemented according to the Law. General Election (Pemilu) is the system of the Republic of Indonesia in determining the order of the running of the Government in Indonesia, both the Legislative Election, President and Vice President, and Heads of Region 1 (one) and level 2 (two) regions. Particularly in this case, the General Election of Regional Heads whose regulations are regulated in Law Number 10 of 2016 concerning the Second Amendment to Law Number 1 of 2015 concerning Stipulation of 


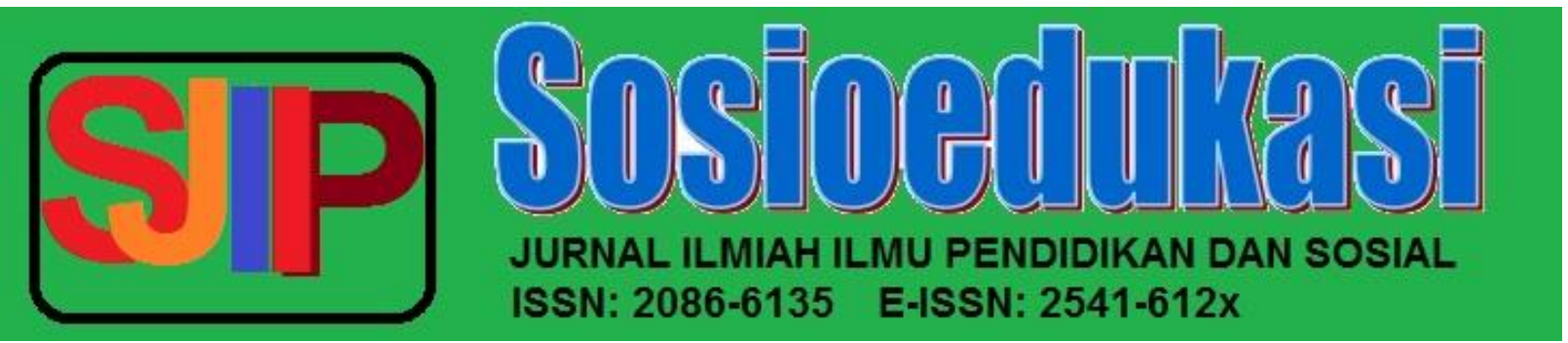

November Vol.9 No. 2 Tahun 2020 https://ejournal.unibabwi.ac.id/index.php/sosioedukasi/index

Government Regulations in Lieu of Law Number 1 of 2014 concerning Elections of Governors, Regents, and Mayor becomes Law.

Seeing that there are still many disputes over the Regional Head Election that have occurred need to be discussed, while within its authority the Constitutional Court of the Republic of Indonesia becomes a forum for dispute resolution during the Regional Head Election. Gafar (2013) Constitutional Courts are mostly formed in

countries that have undergone a process of democratization, transition from authoritarian regimes to states. In its development, the Constitutional Court has been established in countries undergoing a process of democratization, the transition from authoritarian regimes to states. The authority of the Constitutional Court is in relation to the mistake in counting votes which are determined nationally, as long as it affects the election of a candidate or pair of candidates, or affects the seat acquisition of a political party. Election violation cases that are criminal in nature fall under the authority of the general judiciary and administrative violations fall under the authority of the supervision and administration.

The authority of the Constitutional Court institution in juridical settlement of Pilkada disputes is regulated in Law Number 8 of 2011 concerning the Constitutional Court, however in this case it is not clearly regulated, but hierarchically regulated in more detail in the Constitutional Court regulations itself. In practice, the dispute resolution in the Regional Head Election is considered not very effective at this time, reflecting on the dispute over the Regional Head Election in Intan Jaya Regency, Papua, in its implementation, the dispute requested starting from May 23, 2017 has been granted by the Constitutional Court to dispute which is one of the duties, functions, and its authority as a dispute resolution institution for Pilkada, which is completed on 29 August 2017 is considered too long, even though ideally according to the legislation it is only 45 (forty five) working days, as according to the new Legislation in Article 157 paragraph (8) Law Number 10 of 2016 as amended and supplemented by Law Number 15 of 2011 concerning the Election of Governors and Deputy Governors, Regents and Deputy Regents, Mayors and Deputy Mayors so that raises questions about the institutional electability of the Constitutional Court in resolving disputes at the General Election of Accountants The ability and electability of the Constitutional Court in resolving disputes in the previous reflection also created a separate polemic, seeing the time that was held in the dispute resolution above, resulting in a decline in democracy that occurred in the Intan Jaya area, Papua, regarding the integrity of the Regional Head Election. 


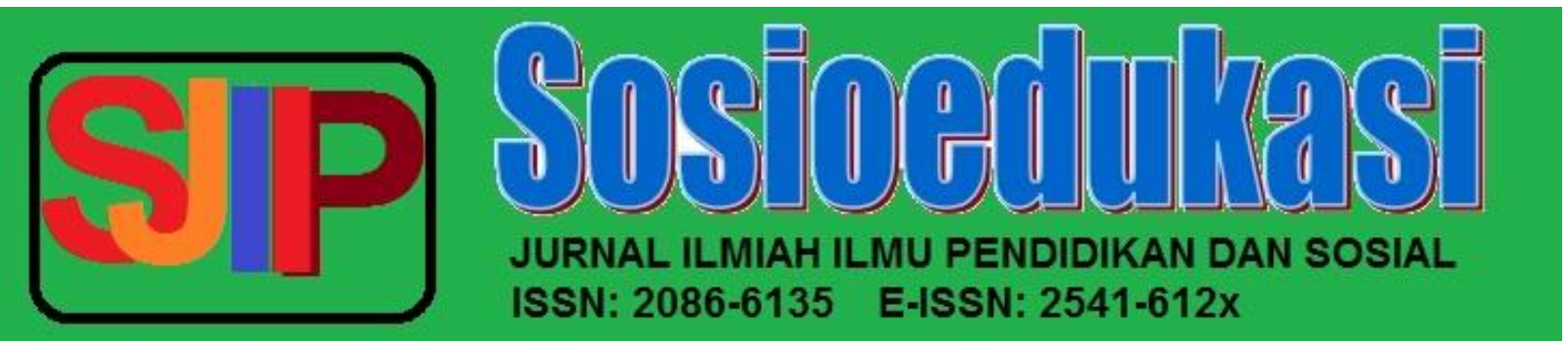

November Vol.9 No. 2 Tahun 2020 https://ejournal.unibabwi.ac.id/index.php/sosioedukasi/index

In this case, through a qualitative descriptive approach, it is found that several problems that affect the effectiveness of Pemilukada dispute resolution in the Constitutional Court are the centralistic nature of the Constitutional Court which

causes problems of access to justice considering that the territory of the Unitary State of the Republic of Indonesia is very large, the number of judges is only nine people, time a brief settlement and expansion of the authority of the Constitutional Court through its decision (Pulguna, 2007).

\section{MATERIALS AND METHODS RESEARCH LOCATION}

method used in this research is juridical normative research method, namely the materials collected by conducting a literature study.

\section{RESULTS AND DISCUSSIONS}

Legal Basis The Authority of the Constitutional Court in Resolving Disputes on the Results of Regional Head Elections in Indonesia The Constitutional Court is one of the actors of judicial power, in addition to the Supreme Court as referred to in Article 24 paragraph (1) of the 1945 Constitution of the Republic of Indonesia. This means that the Constitutional Court is bound by the general principles of the administration of an independent judicial power, free from the influence of the powers of other institutions in upholding law and justice. The Constitutional Court based on Article 24C paragraph (1) of the 1945 Constitution of the Republic of Indonesia has the authority to: a) Examine laws against the 1945 Constitution of the Republic of Indonesia; b) Resolving disputes over the authority of state institutions whose powers are granted by the 1945 Constitution of the Republic of Indonesia; c) Deciding to dissolve political parties; d) Resolving disputes over the results of general elections; and e) Give a decision on the opinion of the DPR that the President and / or Vice President are suspected of having committed a violation of the law in the form of treason against the state, corruption, bribery, other serious crimes, or disgraceful acts, and / or no longer qualify as President and / or Vice President as referred to in the 1945 Constitution of the Republic of Indonesia (UUD, 1945).

The nature of the decision of the Constitutional Court is declarative and constitutive, where the declarative decision creates a condition that is lawful according to law and the constitutive decision removes a situation and creates a new legal state. In reviewing the Law against the Basic 


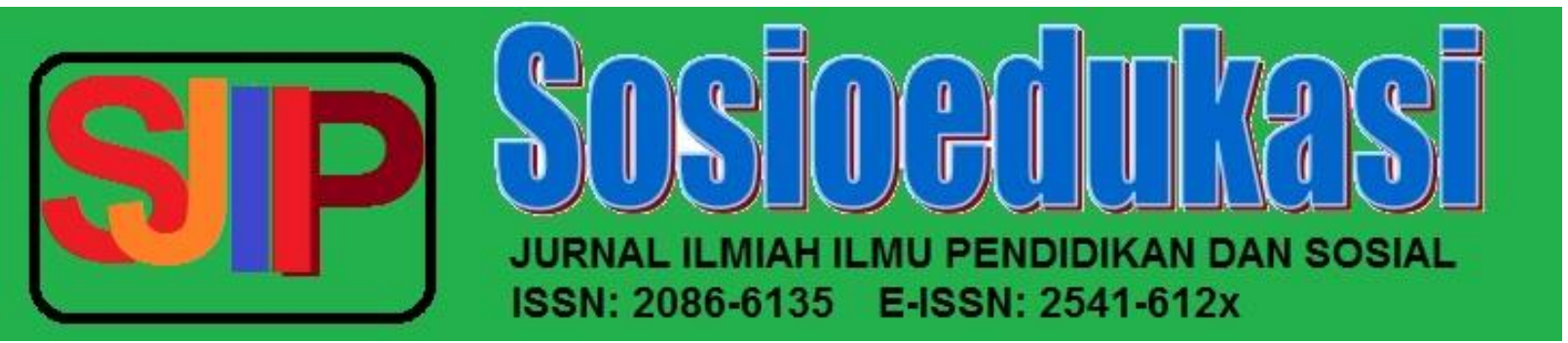

November Vol.9 No. 2 Tahun 2020 https://ejournal.unibabwi.ac.id/index.php/sosioedukasi/index

Law, when granting a petition it is a decision that states a legal condition, at the same time the decision negates a legal condition, and

creates a new legal condition (Slahaan, 2005) The Constitutional Court which has the functions and the position as guardian of the constitution, guarantees the implementation of a responsible state life based on the will of the people and the ideals of democracy. Therefore, the Constitutional Court must guard the constitution by maintaining that the principles of the Election are carried out in the Pemilukada process, not only about disputes over numbers determined by the KPU, but will explore material truth and justice, by assessing whether the Election violations were carried out systematically, massive, and which will significantly affect the final results of the General Election (Mochtar, 2010).

The effectiveness of the Constitutional Court's authority in Regional Head Election Disputes The regional head general election in 2017 is the second simultaneous Pilkada process after the completion of the simultaneous Pilkada process in 2015. The General Election Commission (KPU) is holding simultaneous Pilkada in 101 regions, both provincial and district levels. and Kota in 2017. The simultaneous regional elections in 2017 have entered the final stage, namely the determination of the election results, thus the following stage remains the inauguration of regional heads and deputy regional heads. However, regions that are still unable to accept the determination of the results can file a dispute over the results of the Pilkada at the Constitutional Court. Law Number 10 of 2016 concerning the Election of Governors, Regents and Mayors has provided room for 2017 Pilkada participants to submit Result Disputes to the Constitutional Court with several requirements such as the length of time for submitting Pilkada dispute requests and the voting threshold for election results disputes.

The submission of dispute / dispute over Pilkada results is submitted to the Constitutional Court as long as a special judicial body has not yet been established to adjudicate cases of dispute over the results of the Pilkada as regulated in Article 157 paragraph (1) to paragraph (4) Then in filling government positions in the regions, it is regulated in Law Invite Pilkada. Submission of this application is not necessarily unconditional, but is limited by strict rules of the game. Among them are related to who the applicant is, the expiration of the application, and the threshold requirement for the difference in the petition for votes. Of the 101 regions that held simultaneous Pilkada in 2017, since the concurrent election results were determined by the general election commission in several regions both at the provincial and district / city, 


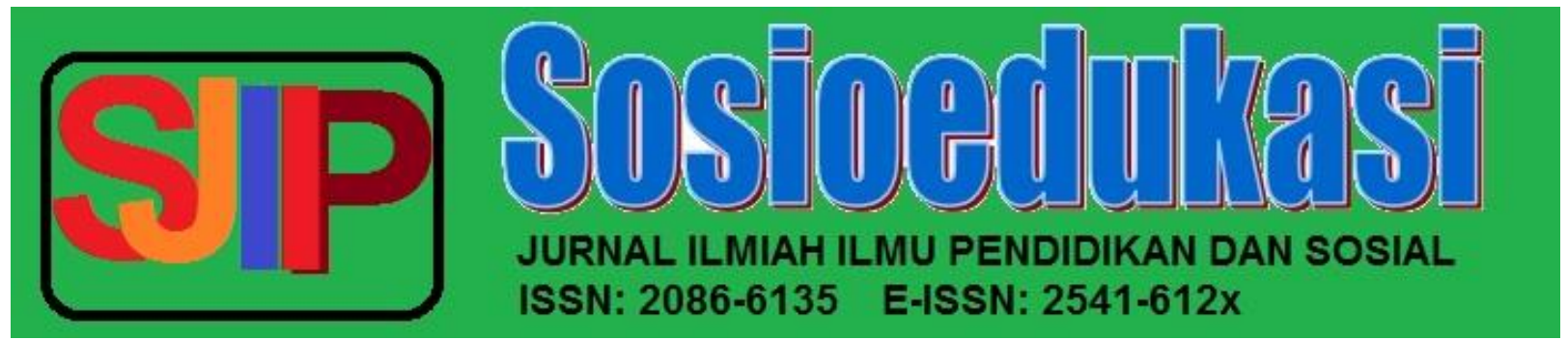

November Vol.9 No. 2 Tahun 2020 https://ejournal.unibabwi.ac.id/index.php/sosioedukasi/index

levelsthere were 53 requests for disputes over the results of the 2017 simultaneous Pilkada that were accepted and decided by the Constitutional Court. both on dismissal / dismissal decisions (preliminary examinations) and final decisions. Although there were 53 requests submitted to the Constitutional Court, based on the regions, there were only 48 disputed regions. This is because there are several regions proposed more than once by different pairs of candidates. Based on the data contained in the Request for Dispute Results of Regional Election at the 2017 Constitutional Court, districts and cities in the Provinces of Aceh and Papua are the regions that have submitted the most disputes to the Constitutional Court. .

This is because these two provinces do have areas that hold quite a lot of simultaneous regional elections for 2017. Aceh Province, held Pilkada in 20 districts / cities out of 23 regencies / cities. Meanwhile, Papua was followed by 11 Regencies / Cities from 29 Regencies / Cities. In the dispute over the results of the 2017 Regional Head Election, Papua Province is the province with the most Pilkada implementation being sued to the Constitutional Court. There are 13 applications registered by the Constitutional Court from 9 regions in Papua Province, namely Dogiyai Regency, Intan Jaya Regency, Lanny Jaya Regency, Mappi Regency, Puncak Jaya Regency, Sarmi Regency, Tolikara Regency, Yapen Islands Regency, and Jayapura City.

As for the 53 petitions for dispute over the 2017 Pilkada results, the arguments submitted by the applicants were classified into 7 categories, the first, the arguments most frequently submitted by the applicants, namely related to the DPT Manipulation (Permanent Voters List) as many as 19 applications; second, related to the argument for the Neutrality of Pilkada Administrators, which is the second largest argument, namely 16 applications; third, there were 6 applications that were submitted due to Vote Reduction. Then the fourth is the argument for the 6 petition related to Money Politics, the fifth is related to the argument for the petition stating that there are 3 voting errors in the vote count, the sixth is related to the Nomination Requirements for 2 applications, then the last seventh is related to the politicization of the bureaucracy as much as 1 application. . In relation to vote count errors, there were various forms of vote counting errors argued by the petitioners, one of which was about the

error that there was a difference in the number of voter data between the recapitulation made by the KPU and the C1-KWK form. As for the distribution of regions that submitted applications based on the arguments of the petition, vote count errors had occurred as happened to the elections in Intan Jaya Regency. 


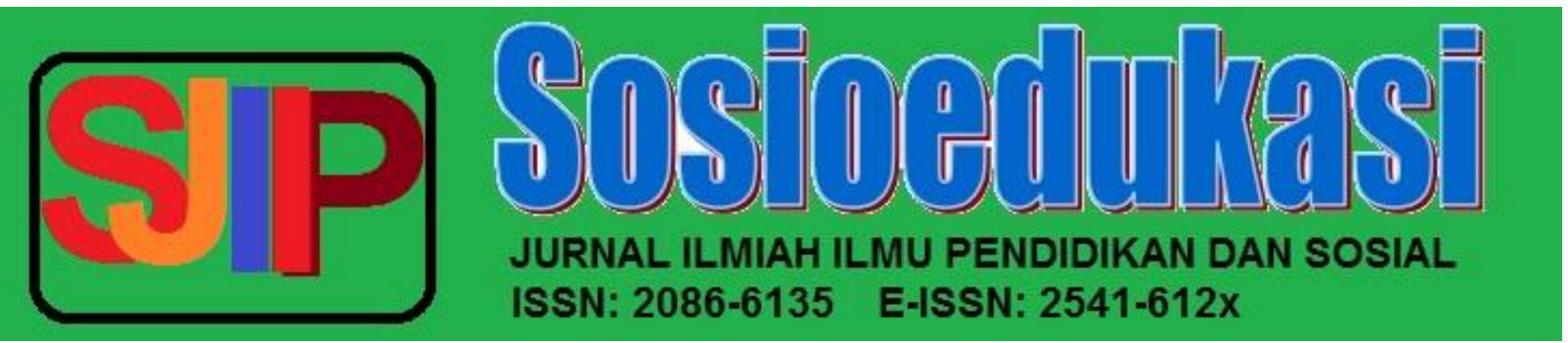

November Vol.9 No. 2 Tahun 2020 https://ejournal.unibabwi.ac.id/index.php/sosioedukasi/index

Related to the verdict against the Kab. Intan Jaya with the decision to conduct Advanced Vote Count Recapitulation, this is due to the fact that there are ballot papers from 7 polling stations in 2 districts that have not yet been recapitulated on the vote count results because the open plenary meeting to recapitulate the vote count had to be stopped, the Court in legal considerations stated that The recapitulation carried out in Intan Jaya Regency still left problems so that it did not provide legal certainty and delayed the issuance of Decree (SK) regarding the recapitulation of vote count results. Based on this, the Constitutional Court stated that there was no decision by the KPU Kab. Intan Jaya regarding the determination of the recapitulation of vote count results and the election results for the regent and deputy regent of Diamond Jaya in 2017 so that there is no object of dispute, and further recapitulation of vote counts is required in 7 polling stations in 2 districts. The results of the recap were combined with the existing votes acquired and the Recapitulation Decree was then issued. This recapitulation decree can later be used as the object of a new application to the Constitutional Court if there are parties or pairs of candidates who feel disadvantaged.

If we look at the differences in the results of the Pilkada determined by the local KPU, the threshold for the difference in votes required by Article 158 Then in filling government positions in the regions, regulated in Law Number 8 of 2015 is not fulfilled. In the Constitutional Court Decision, there was an order to carry out further vote recapitulation at 7 polling stations that had not yet been implemented in Intan Jaya Regency which was subsequently combined with the existing vote acquisition. However, the decision related to Intan Jaya Regency can be said to be an anomaly of the Constitutional Court's decision, this is because in Legal Considerations number [3.6] the Constitutional Court states that it is necessary to carry out Advanced Vote Recapitulation on 7 polling stations that have not been counted, which will then be combined with the acquisition of votes. the existing votes, then after that a Decree on the Recapitulation of Vote Counting and the Determination of the Elected Paslon by 41 KPU Kab. Intan

Jaya, but the Constitutional Court stated that the decree resulting from the recapitulation of the advanced votes could be used as the object of a new petition to the Constitutional Court.

The dispute over the results of the Intan Jaya Regional Head Election that was requested by Candidate Pair Bartolomius Similar and Deny Miagoni, the KPU has not had the chance to count ballots at 7 polling stations due to intimidation, threats, persecution and riots between candidate pairs. Initially the count would be continued in Jakarta under the supervision of the KPU and Bawaslu, but because one of the candidate pairs had submitted a case to the Constitutional Court before the count was continued, the recapitulation was discontinued. Due to these extraordinary 


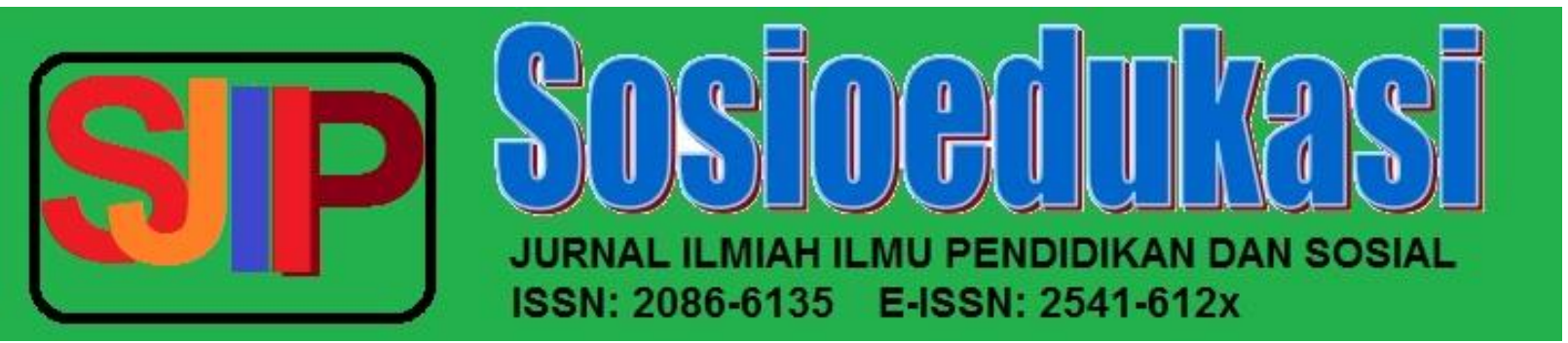

November Vol.9 No. 2 Tahun 2020 https://ejournal.unibabwi.ac.id/index.php/sosioedukasi/index

circumstances, the Constitutional Court decided that the vote count should be continued for 14 working days to be written into the KPU decision letter of the Intan Jaya Regency regarding the recapitulation of the vote count results. It becomes an anomaly when looking at the provisions in Article 24C paragraph (1) of the 1945 Constitution of the Republic of Indonesia which confirms that the Constitutional Court adjudicates cases at the first and last levels whose decisions are final, but in the Constitutional Court's decision regarding the dispute over the results of the Regional Election of Intan Jaya Regency. Mahakamah provides more space for parties (regent and deputy regent candidate pairs of Intan Jaya Regency) to reapply for the District KPU Decree. Intan Jaya which is the result of the Recapitulation of the Votes of the Constitution itself.

In the trial, the Petitioner also argued that the forms and certificates used in the 2017 Intan Jaya Regent and Deputy Regent Election contradicted the principles of the Constitutional Court to order the General Election Commission (KPU) of Papua Province to recapitulate further vote counts in the Election of Regent and Deputy Regent of Intan Jaya Regency. 2017. This was revealed in the hearing of the pronouncement of Decision Number 50 / PHP.BUPXV / 2017 on Monday (3/4) in the Plenary Meeting Room of the Constitutional Court Building. According to the Constitutional Court, there has been no Decree of the KPU of Intan Jaya Regency regarding the Determination of the Recapitulation of Vote Count Results and the Election Results of Intan Jaya Regent and Deputy Regent of 2017 which are definitive. Therefore, there is no object of dispute as referred to in Article 157 paragraph (4) Then in filling government positions in the regions, it is regulated in Law Number 10/2016.

In decision number 54 / PHP.BUP-XV / 2017 filed by Candidate Pair number 3, namely Natalis Tabuni, SS, M.Si and Yann Robert Kobogoyauw, S.Th., M.Div as their petition has been granted by the Constitutional Court since Tuesday, 23 May 2017 it was judged that it stipulated that there was a recapitulation of 7 (seven) TPS which was subsequently combined with the results of the Recount conducted by the Court of all TPS which were not ordered to re-vote. Then in the verdict on Tuesday, August 29, 2017, the correct vote count results of each pair of candidates were determined in a re-voting which resulted in Candidate Pair number 3 getting the most votes from the Regional Head Election 2017.

The Constitutional Court as the oversight institution The dispute over Regional Head Election is considered ineffective in its implementation, because considering the previous polemic of the Constitutional Court as the institution that covers disputes over Regional Head Elections, it is considered not yet effective in its implementation, because considering the previous polemic 


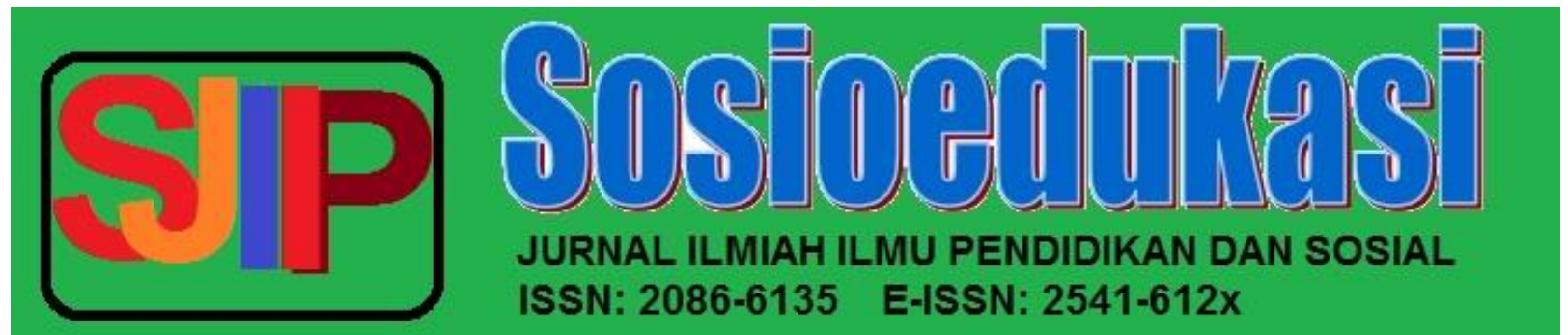

November Vol.9 No. 2 Tahun 2020 https://ejournal.unibabwi.ac.id/index.php/sosioedukasi/index

\section{CONCLUSION}

1. The existence of the Constitutional Court in Indonesia, namely as the guardian of the constitution and interpreter of the constitution towards a democratic rule of law is very important. The authority of the Constitutional Court in judging at the first and last levels whose decisions are final to decide disputes over general elections, there are several paragraphs that discuss the extent to which the authority of the Constitutional Court in resolving disputes over the General Election of Regional Heads has been contained in Article 157 of Law Number 10 of 2016 concerning Second Amendment to Law Number 1 of 2015 concerning Stipulation of Government Regulations in Lieu of Law Number 1 of 2014 concerning Elections for Governors, Regents and Mayors which form the legal basis for the authority of the Constitutional Court in resolving disputes over the results of the General Election in Indonesia

2. In handling disputes Pemilukada, the Constitutional Court as the institution that covers and adjudicates the first and final stages are considered not yet effective. Reflecting on the dispute over the Regional Head Election in Irian Jaya Regency, Papua, in its implementation the dispute requested starting from 23 May 2017 was granted by the Constitutional Court to be disputed, which is one of its duties, functions, and authorities as an election dispute settlement institution, and was completed on 29 August 2017 is considered too long, even though ideally according to statutory regulations only 45 (forty five) working days, as according to the new Laws and Regulations In Article 157 paragraph (8) of Law Number 10 Year 2016 as amended and added from Law Number 15 Year 2011 concerning the Election of the Governor and Deputy Governor, Regent and Deputy Regent, Mayor and Deputy Mayor

\section{REFERENCES}

Peraturan Undang-Undang Dasar Republik Indonesia Tahun 1945.

Undang-Undang Nomor 8 Tahun 2012 tentang Pemilihan Umum Anggota DPR, DPD, dan DPRD.

Undang-Undang Nomor 30 Tahun 2014 tentang Administrasi Pemerinatahan. 


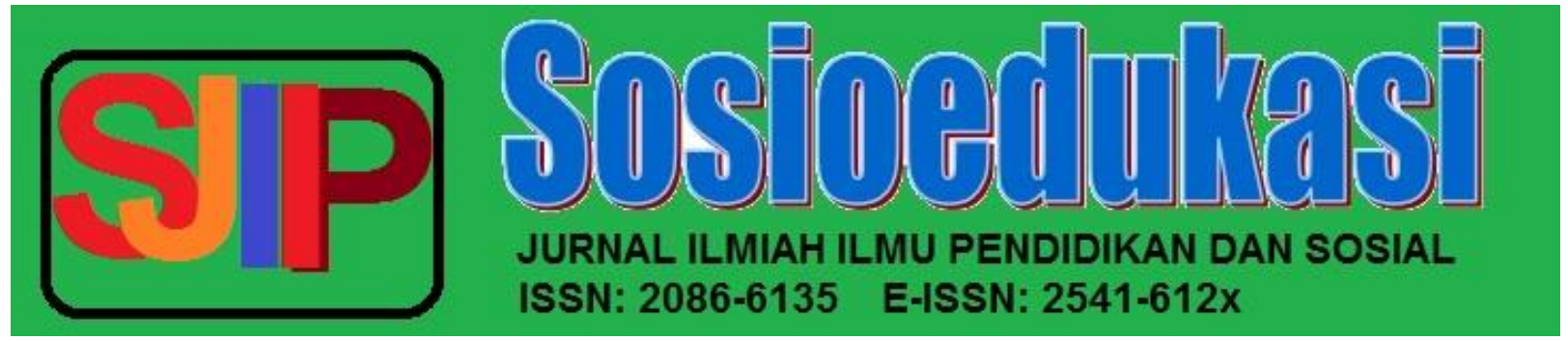

November Vol.9 No. 2 Tahun 2020 https://ejournal.unibabwi.ac.id/index.php/sosioedukasi/index

Undang-Undang Nomor 23 Tahun 2014 tentang Pemerintahan Daerah.

Putusan Mahkamah Konstitusi Nomor 15 Tahun 2008 tentang Pedoman Beracara dalam Perselisihan Hasil Pemilihan Umum Kepala Daerah.

Putusan Mahkamah Konstitusi Nomor 97/PUUXI/2013. Putusan Mahkamah Konstitusi Nomor 54//PHP.BUP-XV/2017

Jimly, A. 2006. Sengketa Kewenangan Konstitusional Lembaga Negara. Sekjen dan Kepaniteraan Mahkamah Konstitusi RI.

Jimly, A. 2016. Pengantar Ilmu Hukum Tata Negara Jilid I. Jakarta: Sekretariat Jenderal dan Kepaniteraan Mahkamah Konstitusi RI.

Harun, A. 1997. Pemilihan Presiden dan Pergantian Presiden Dalam Hukum Positif Indonesia. Jakarta: Yayasan Lembaga Bantuan Hukum Indonesia.

Andriansyah. 2015. Administrasi Pemerintahan Daerah dalam Kajian dan Analisa. Jakarta Pusat: Fakultas Ilmu Sosial dan Ilmu Politik Universitas Prof. Dr. Moestopo Beragama.

Prajudi, A. 1981. Hukum Administrasi Negara. Jakarta: Ghalia Indonesia.

Aziz, N. M. 2011. Pengkajian Hukum Tentang Pemilihan Kepala Daerah. Jakarta: Badan Pembinaan Hukum Nasional Kementerian Hukum dan Hak Asasi Manusia RI.

Ikhsan, D dan Parluhutan, R. 2006. Makhamah Konstitusi: Memahami Keberadaannya Dalam Ketatanegaraan Republik Indonesia. Jakarta: PT Rineka Cipta.

Departemen Pendidikan dan Kebudayaan Republik Indonesia. 1988. Kamus Besar Bahasa Indonesia. Jakarta: Balai Pustaka.

Gaffar, J. 2013. Hukum Pemilu Dalam Yurisprudensi Mahkamah Konstitusi, Jakarta: Konstitusi Press. 